\section{Compelling curiosity of naturalists}

A World of Naturalists. By J. Kastner. Pp.350. (John Murray: London, 1978.) $£ 7.95$.

ONE reviewer of J. Bigelow's American Medical Botany (1817-20) expressed "a concern that too few American botanists were actively studying the plant life of their country . . . While we ourselves were devoted to the more profitable employment of commerce and agriculture, a Catesby, a Kalm, a Michaux or a Pursh was reaping a harvest of fame on our soil, and teaching us to admire the grandeur of our majestic forests and luxuriant savannahs." Although there were native-born American naturalists like the Bartrams, Mr Kastner's book is largely a chronicle of the achievements of those immigrant naturalists who confounded the parochial view of the French naturalist, Comte de Buffon, that the fauna and flora of the New World were inferior to those of the Old World.

Starting with John Banister, a young clergyman who went to Virginia in 1678 resolved to write an account of its natural history, Mr Kastner follows the progress of American natural history through the activities of such men as Peter Kalm (one of Linnaeus's favourite pupils); and André Michaux and Thomas Nuttall, whose floras of North America remained standard works for many years. The first native American botanist, John Bartram, whose garden in Philadelphia is now regarded as the first true botanical garden in North America, collected plants for European gardens and was made the King's botanist in America. The Travels through North and South Carolina [etc] (1791) by his son William, likewise a plant-collector, was the source of much of Coleridge's poetic imagery.

The generous extracts $\mathrm{Mr}$ Kastner provides from journals, letters and published works convey vividly the wonder and astonishment evoked by the discovery of so many new plants and animals. The determination of these early naturalists to bring back specimens of what they saw was not without considerable danger to themselves. John Lawson, who like Banister before him had intended to write a natural history of Virginia, suffered a lingering death at the hands of hostile Indians who ignited small splinters of wood stuck all over his body.
The story of American natural history as it emerges from the pages of $\mathrm{Mr}$ Kastner's book is also the story of the discovery and exploration of the North American continent.

What all naturalists have in common is a compelling curiosity. Thomas Nuttall earned for himself the nickname 'Old Curious' and Constantine Rafinesque, oblivious of the ridicule of his contemporaries, reported the results of his insatiable curiosity in a flood of papers that are only now being fully appreciated by scientists. It was Rafinesque who said that although "a life of travels and exertions has its pleasures and pains... you feel an exultation, you are a conqueror, you have made a conquest over nature, you are going to add a new object, or a page to science".

With such remarkable and idiosyncratic men as those in his subject, $\mathrm{Mr}$ Kastner could not fail to write an absorbing book. His bibliography testifies to the extent of his research, and the illustrations, including a number in colour, are well chosen.

Ray Desmond

Ray Desmond is Deputy-Keeper at the India Office Library and Records and a Past-President of the Society for the Bibliography of Natural History.

\section{Tumour immunology}

Immunological Aspects of Cancer. Edited by J. E. Castro. Pp. 477. (MTP Press: Lancaster, UK, 1978.) £14.75.

Tumour immunology has reached another stage in its tortuous evolution where doubts are being voiced as to the wisdom of its rapid expansion in recent years. It is perhaps unfortunate, therefore, that this new multi-author book should appear just at the time when a reappraisal is being made of the many immunological approaches to cancer. In consequence, the reader will find little about the latest 'popular developments', such as the role of natural killer cells in immunosurveillance. One would, therefore, expect a critical account of the past achievements in tumour immunology, so that the reader can be led into the subject and decide whether it has any appeal. This objective is only partially fulfilled and it is unfortunate that a number of the chapters show the author's own prejudices all too readily.

The basic concepts of tumour immunology as defined in animal systems are reviewed in a concise manner. Michael Moore's summary of neoantigens in animal tumours is of particular value, even though spontaneous tumours are not given the attention they deserve. The role of effector cells ( $T$ lymphocytes and macrophages) in tumour rejection and the effects of humoral factors modifying these responses are also well presented. At least here the authors point out many of the shortcomings of the approach being used to study immunity to cancer. The critical approach adopted by Suzanne Eccles in reviewing the role of macrophages is particularly appealing and Peter Beverley's account of $T$ lymphocytes is excellent, even though too concise for the non-specialist.

It is when one moves to considerations of the role of immunological factors in human cancer that judgement becomes clouded by optimism. For example, the brief review of in vitro methods for detecting human tumour-associated antigens leaves one with the impression that none of the approaches are adequately developed to command widespread acceptance. Yet the reader learns later that these techniques can be used for evaluating immune reactions in cancer or even for immunodiagnosis. The same dichotomy is revealed in the chapters dealing with immunotherapy. The

\section{SENSORY WORLD \\ Hallmark of reporting}

A quarterly communicating significant factors in sensory and contiguous areas

\section{Brings you}

'Papers - research reports of highest calibre

Developments - innovative work as it happens

World Literature - comprehensive spectrum of references, by schedule

$\$ 18 /$ year; overseas $\$ 20$ (outside USA add $\$ 2.80$ )

$$
\begin{aligned}
& \text { P.O. Box 270, Lusby, } \\
& \text { MD 20657, USA }
\end{aligned}
$$

